\title{
Detection of shellfish toxins from scallops in Guangzhou seafood market
}

\author{
Huazhang L (1), Wen-xue L (1), Quan-xin Z (1), Guang-yu Y (1), Jun-tao L (1), Li M (2), Wei Z (1)
}

(1) Department of Toxicology, Guangzhou Center for Disease Control and Prevention, Guangzhou, Guangdong, People's Republic of China; (2) Department of Preventive Medicine, Guangzhou Military Region CDC, Guangzhou, People's Republic of China.

\begin{abstract}
To evaluate scallop safety in the Guangzhou seafood market, contents of shellfish toxins in adductor muscle, mantle skirts, gills and visceral mass of scallops were examined using enzyme-linked immunosorbent assay (ELISA) and mouse unit assay. The results showed that: paralytic shellfish poisoning contents were up to $37.44 \mu \mathrm{g} / 100 \mathrm{~g}$ by ELISA and $319.99 \mathrm{MU} / 100 \mathrm{~g}$ by mouse unit assay, which did not exceed the limits of national standards $(80 \mu \mathrm{g} / 100 \mathrm{~g}$ and $400 \mathrm{MU} / 100 \mathrm{~g})$; the contents of diarrhetic shellfish poisoning were $142.04 \mu \mathrm{g} / 100 \mathrm{~g}$ and $0.2 \mathrm{MU} / 100 \mathrm{~g}$, which exceeded the national standard limits (60 $\mu \mathrm{g} / 100 \mathrm{~g}$ ); neurotoxic shellfish poisoning was undetectable; the contents of amnesic shellfish poisoning reached $220.12 \mu \mathrm{g} / 100 \mathrm{~g}$ (no limit value could be referred to) . In addition, these poisons were present mainly in visceral mass and gills rather than adductor muscle and mantle skirts, suggesting that these toxins accumulate in a tissue-specific manner.
\end{abstract}

Key words: paralytic shellfish poisoning, diarrheic shellfish poisoning, neurotoxic shellfish poisoning, amnesic shellfish poisoning, enzyme-linked immunosorbent assay, mouse unit assay.

\section{INTRODUCTION}

Shellfish mainly feed on single-celled marine algae (1). Thus, toxins in some algae can be accumulated or metabolized by shellfish and eventually transformed into shellfish toxins (2-6). There are four types of shellfish toxins: paralytic shellfish poisoning (PSP), diarrhetic shellfish poisoning (DSP), neurotoxic shellfish poisoning (NSP) and amnesic shellfish poisoning (7). Among these, PSP and DSP are most harmful to humans (8).

In recent years, scallop poisoning incidents have occurred frequently in Guangdong province and in its neighbors Hong Kong and Macao. To evaluate the situation of scallop contamination and to oversee the safety of the scallop market, the above four shellfish toxins in scallops from the Guangdong seafood market were examined using enzyme-linked immunosorbent assay (ELISA). Besides, PSP and DSP were also detected with mouse unit assay in order to verify the ELISA results.

\section{MATERIALS AND METHODS}

\section{Materials and Reagents}

PSP, DSP, NSP and ASP detection kits were purchased from Abraxis BioScience (USA). Fresh scallops originated from Shandong and Zhanjiang were obtained from the Guangzhou seafood market.

\section{Experimental Animals}

Healthy special pathogen-free KM mice, weighing 19 to $21 \mathrm{~g}$, were provided by Guangdong Medical Experimental Animal Center (Guangzhou, China). Animals were killed 
by asphyxiation with $\mathrm{CO}_{2}$. The experimental protocol followed the "Declaration of Helsinki" and was approved by the Ethics Committee for Animal Experimentation of the Guangzhou Center for Disease Control and Prevention.

\section{Sample Preparation}

Shells of scallops were opened by cutting along the adductor muscles. Their adductor muscles, gills, mantle skirts and visceral masses were collected, homogenized and stored at $-20^{\circ} \mathrm{C}$ for future use. Figure 1 shows the opened scallops and their organs. The scallops from the Shandong sea area were larger than those from the sea area of Zhanjian although both of them belong

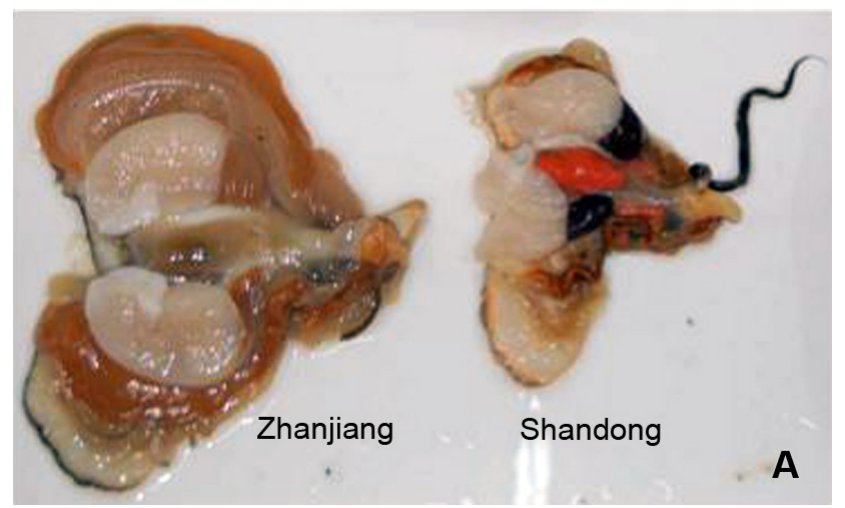

to the same species of Placopecten megallancius, according to the identification report by South China Sea Institute of Oceanography, Chinese Academy of Sciences.

\section{PSP Measurement}

PSP was measured by ELISA and mouse unit assay. For ELISA, $10 \mathrm{~g}$ of obtained homogenate was mixed with $10 \mathrm{~mL}$ of $0.1 \mathrm{~mol} / \mathrm{L} \mathrm{HCl}$. After being boiled for five minutes under stirring, the mixture was centrifuged at $3500 \mathrm{~g}$ for ten minutes at $4^{\circ} \mathrm{C}$. The obtained supernatant was adjusted to $\mathrm{pH} 4.0$ using $5 \mathrm{~mol} / \mathrm{L} \mathrm{HCl}$. After undergoing 1000 -fold dilution with sample buffer, the PSP level was detected using the ELISA kit according to the protocol provided by the manufacturer.

For the mouse unit assay, $10 \mathrm{~g}$ of homogenate was mixed with $10 \mathrm{~mL}$ of $0.1 \mathrm{~mol} / \mathrm{L} \mathrm{HCl}$ and adjusted to a pH between 2.0 and 4.0 with 5 $\mathrm{mol} / \mathrm{L} \mathrm{HCl}$. After boiling for five minutes, samples were adjusted to a $\mathrm{pH}$ from 2.0 to 4.0 at room temperature again and centrifuged at $3000 \mathrm{~g}$ for five minutes.

The obtained supernatant was used in the mouse unit assay as follows. Mice were weighed on a balance with $0.1 \mathrm{~g}$ sensitivity. Each of the

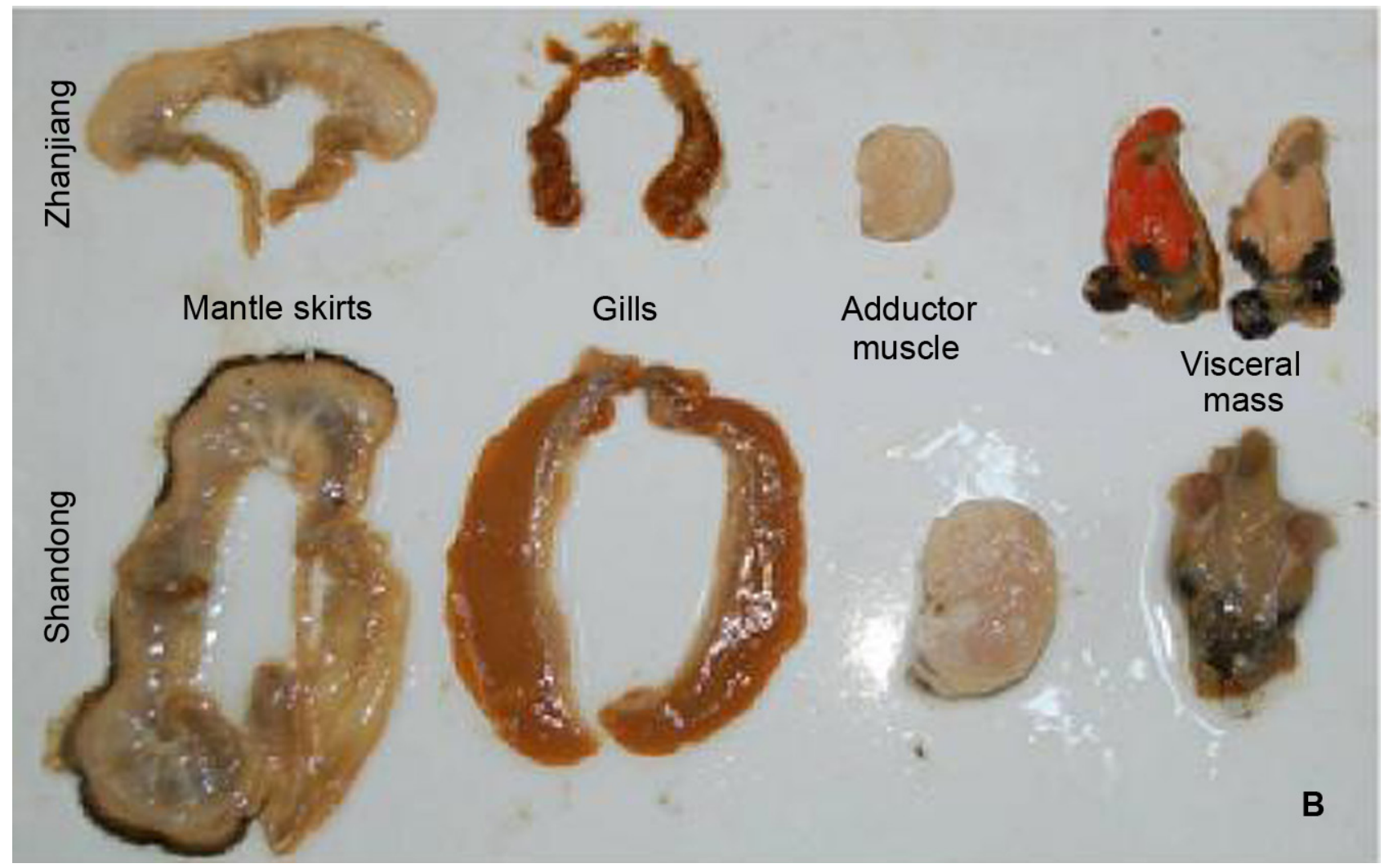

Figure 1. Anatomy of scallops from Zhanjian and Shandong. 
three control mice was intraperitoneally injected with $1 \mathrm{~mL}$ of $\mathrm{HCL}$ with $\mathrm{pH}$ ranging from 2.0 to 4.0 and another three mice were similarly injected with $1 \mathrm{~mL}$ of supernatant. Their performance and death time were recorded. If at least one mouse died within seven minutes after injection, the experiment was performed one more time to determine the toxicity of the sample. If any mouse died in less than five minutes, the experiment was performed again using diluted sample until a mouse died within 5 to 7 minutes.

The content of PSP was calculated as the number of mouse units per $100 \mathrm{~g}$ of scallop based on the recorded death time of each mouse, correlation curve of PSP death time to mouse unit and body weight correction, as shown in Table 1 $(6,9)$. Data were expressed as mean value of three experiments.

\section{DSP Measurement}

DSP was measured by ELISA and mouse unit assay. For ELISA, $1 \mathrm{~g}$ of homogenate was extracted with $6 \mathrm{~mL}$ of $80 \%(\mathrm{v} / \mathrm{v})$ methanol and centrifuged at $3500 \mathrm{~g}$ for ten minutes at $4^{\circ} \mathrm{C}$. The pellet was repeatedly extracted with $2 \mathrm{~mL}$ of $80 \%$ methanol until the total volume of the collected supernatant reached $10 \mathrm{~mL}$. The supernatant was then filtered through a $0.45-\mu \mathrm{m}$ membrane,

Table 1. Minimum injection amount and maximum dilution fold of shellfish poisonings that caused the death of two or more mice within 24 hours

\begin{tabular}{c|c|c}
\hline Sample & $\begin{array}{c}\text { Injection } \\
\text { volume (2) }\end{array}$ & $\begin{array}{c}\text { Mouse unit } \\
\text { value (MU/g) }\end{array}$ \\
\hline $\begin{array}{c}\text { Stock } \\
\text { solution }\end{array}$ & 1.0 & 0.05 \\
\hline $\begin{array}{c}\text { Stock } \\
\text { solution }\end{array}$ & 0.5 & 0.1 \\
\hline $1 / 2$ diluent & 1.0 & 0.1 \\
\hline $1 / 2$ diluent & 0.5 & 0.2 \\
\hline $1 / 4$ diluent & 1.0 & 0.2 \\
\hline $1 / 4$ diluent & 0.5 & 0.4 \\
\hline $1 / 8$ diluent & 1.0 & 0.4 \\
\hline $1 / 8$ diluent & 0.5 & 0.8 \\
\hline $1 / 16$ diluent & 1.0 & 0.8 \\
\hline $1 / 16$ diluent & 0.5 & 1.6 \\
\hline
\end{tabular}

diluted 1000-fold and used for ELISA analysis according to the manufacturer's protocol.

For the mouse unit assay, $200 \mathrm{~g}$ of homogenate was extracted with $600 \mathrm{~g}$ acetone under stirring and filtered with a Büchner funnel. The pellet was re-extracted with acetone twice. The extracts were combined together, transferred into a 500$\mathrm{mL}$ flask and vacuum concentrated at $56^{\circ} \mathrm{C}$ until an oily liquid surface appeared. The concentrated liquid was then completely transferred into a separatory funnel by washing the sticky wall with 100 to $200 \mathrm{~mL}$ of ether and a small amount of water. After removal of the water layer (lower), the ether fraction was washed twice with half the volume of water.

The collected ether fraction was concentrated in a vacuum in a $250-\mathrm{mL}$ conical flask at $35^{\circ} \mathrm{C}$ and further concentrated in a $100-\mathrm{mL}$ conical flask in a vacuum to remove the ether. The obtained sample was diluted with $1 \%$ Tween-60 saline solution to $10 \mathrm{~mL}$. One milliliter of the solution corresponded to $20 \mathrm{~g}$ of the original sample and was used as the starting solution in mouse unit assay performed similarly to the description above except that the assay was repeated if all three mice died within 24 hours and the sample was diluted with $1 \%$ Tween-60 saline solution after extensive shaking. One mouse unit was defined as the amount of toxin that leads to the death of a mouse weighing 16 to $20 \mathrm{~g}$ (6). DSP content was calculated according to Table 1, which lists the required minimum injection amount and maximum dilution fold that cause the death of two or more mice within 24 hours (10).

\section{ASP Measurement}

Four grams of homogenate was mixed with $16 \mathrm{~mL}$ of $50 \%(\mathrm{v} / \mathrm{v})$ aqueous methanol solution and vortexed for one minute. The supernatant was obtained by centrifugation at $3000 \mathrm{~g}$ for ten minutes at room temperature and used to measure ASP content using an ELISA kit according to the manufacturer's protocol.

\section{NSP Measurement}

One gram of homogenate was mixed with $90 \%$ aqueous methanol solution and vortexed for one minute. The supernatant was collected by centrifugation at $3000 \mathrm{~g}$ for ten minutes at room temperature and used to measure ASP content using an ELISA kit according to the manufacturer's protocol. 


\section{RESULTS}

\section{PSP Contents}

The contents of all poisonings measured by ELISA were calculated based on the standard curves. As shown in Table 2, PSP was detected in scallops from both Shandong and Zhanjiang, where samples presented levels that reached $9.67 \mu \mathrm{g} / 100 \mathrm{~g}$ and $37.44 \mu \mathrm{g} / 100 \mathrm{~g}$, respectively, lower than the limit $(80 \mu \mathrm{g} / 100 \mathrm{~g})$ required by the Chinese national standard (11). Furthermore, PSP contents were higher in visceral mass and gills than those in adductor muscle and mantal skirts, suggesting the presence of specific tissue accumulation of PSP in shellfish. PSP contents measured by mouse unit assay are listed in Table 3. The highest PSP content in all samples was 319.9 MU/100 g, lower than the limit (400 $\mathrm{MU} / 100 \mathrm{~g}$ ) for the toxic substance among nonenvironmental pollution aquatic products.

Table 2. PSP contents measured by ELISA in scallops from Shandong and Zhanjiang

\begin{tabular}{|c|c|c|c|c|c|}
\hline Sample & $\begin{array}{l}\text { Adductor } \\
\text { muscle } \\
(\mu \mathrm{g} / 100 \mathrm{~g})\end{array}$ & $\begin{array}{l}\text { Visceral mass } \\
(\mu \mathrm{g} / 100 \mathrm{~g})\end{array}$ & $\begin{array}{l}\text { Mantle skirts } \\
(\mu \mathrm{g} / 100 \mathrm{~g})\end{array}$ & $\begin{array}{c}\text { Gill } \\
(\mu \mathrm{g} / 100 \mathrm{~g})\end{array}$ & Province \\
\hline 1 & $0.65 \pm 0.13$ & $1.59 \pm 0.32$ & $0.9 \pm 0.18$ & $3.81 \pm 0.76$ & Zhanjiang \\
\hline 2 & $2.24 \pm 0.45$ & $23.1 \pm 4.62$ & $8.05 \pm 1.61$ & $11.23 \pm 2.25$ & Zhanjiang \\
\hline 3 & $1.19 \pm 0.24$ & $18.63 \pm 3.73$ & $4.91 \pm 0.98$ & $19.07 \pm 3.81$ & Zhanjiang \\
\hline 4 & $1.04 \pm 0.21$ & $23.21 \pm 4.64$ & $10.85 \pm 2.17$ & $9.66 \pm 1.93$ & Zhanjiang \\
\hline 5 & $0.66 \pm 0.13$ & $6.27 \pm 1.25$ & $1.39 \pm 0.28$ & $2.07 \pm 0.40$ & Zhanjiang \\
\hline 6 & $0.44 \pm 0.09$ & $4.37 \pm 0.87$ & $2.17 \pm 0.43$ & $21.38 \pm 4.28$ & Zhanjiang \\
\hline 7 & $0.86 \pm 0.17$ & $24.58 \pm 4.92$ & $9.86 \pm 1.97$ & $6.59 \pm 1.32$ & Zhanjiang \\
\hline 8 & $0.33 \pm 0.07$ & $8.56 \pm 1.71$ & $2.66 \pm 0.53$ & $20.17 \pm 4.03$ & Zhanjiang \\
\hline 9 & $0.52 \pm 0.1$ & $33.28 \pm 6.66$ & $3.65 \pm 0.73$ & $10.52 \pm 2.1$ & Zhanjiang \\
\hline 10 & $0.33 \pm 0.07$ & $17.31 \pm 3.46$ & $1.81 \pm 0.36$ & $3.27 \pm 0.65$ & Zhanjiang \\
\hline 11 & $0.61 \pm 0.12$ & $37.44 \pm 7.49$ & $3.59 \pm 0.72$ & $22.09 \pm 4.4$ & Zhanjiang \\
\hline 12 & $2.24 \pm 0.45$ & $2.83 \pm 0.57$ & $2.83 \pm 0.57$ & $3.11 \pm 0.62$ & Shandong \\
\hline 13 & $0.15 \pm 0.03$ & $3.11 \pm 0.62$ & $2.71 \pm 0.54$ & $5.51 \pm 1.1$ & Shandong \\
\hline 14 & $0.29 \pm 0.06$ & $5.512 \pm 1.1$ & $2.78 \pm 0.56$ & $5.94 \pm 1.19$ & Shandong \\
\hline 15 & $0.66 \pm 0.13$ & $5.936 \pm 1.19$ & $2.7 \pm 0.54$ & $3.55 \pm 0.71$ & Shandong \\
\hline 16 & $0.15 \pm 0.03$ & $3.555 \pm 0.71$ & $2.82 \pm 0.56$ & $9.67 \pm 1.93$ & Shandong \\
\hline 17 & $0.34 \pm 0.07$ & $9.67 \pm 1.93$ & $1.59 \pm 0.32$ & $3.81 \pm 0.76$ & Shandong \\
\hline
\end{tabular}




\section{DSP Contents}

DSP contents measured by ELISA are listed in Table 4. Scallops from Zhanjiang contained a higher DSP level, peaking at $142.04 \mu \mathrm{g} / 100 \mathrm{~g}$, greater than the limit $(60 \mu \mathrm{g} / 100 \mathrm{~g})$ regulated by Chinese national standard (11). PSP content in scallops from Shandong presented a peaking level of $33.86 \mu \mathrm{g} / 100 \mathrm{~g}$, lower than the limit. Similar to DSP, PSP also accumulated in visceral mass and gills rather than mantle skirts and adductor muscle.
DSP contents measured by mouse unit assay are listed in Table 5. Scallops from Zhanjiang had up to $319.9 \mathrm{MU} / 100 \mathrm{~g}$ of DSP, much higher than the limit (undetectable) for the toxic substance in the non-environmental pollution aquatic products. Consistent with the ELISA results, DSP contents measured by mouse unit assay in visceral mass and gills were higher than those in mantle skirts and adductor muscle.

Table 3. PSP contents measured by mouse unit assay in scallops from Shandong and Zhanjiang

\begin{tabular}{|c|c|c|c|c|c|}
\hline Sample & $\begin{array}{l}\text { Adductor } \\
\text { muscle } \\
(\mathrm{MU} / 100 \mathrm{~g})\end{array}$ & $\begin{array}{c}\text { Visceral mass } \\
(\mathrm{MU} / 100 \mathrm{~g})\end{array}$ & $\begin{array}{l}\text { Mantle skirts } \\
\text { (MU/100 g) }\end{array}$ & $\begin{array}{c}\text { Gill } \\
(\mathrm{MU} / 100 \mathrm{~g})\end{array}$ & Province \\
\hline 1 & $<175$ & $<175$ & $<175$ & $<175$ & Zhanjiang \\
\hline 2 & $<175$ & 197.42 & $<175$ & $<175$ & Zhanjiang \\
\hline 3 & $<175$ & $<175$ & $<175$ & $<175$ & Zhanjiang \\
\hline 4 & $<175$ & 198.39 & $<175$ & $<175$ & Zhanjiang \\
\hline 5 & $<175$ & $<175$ & $<175$ & $<175$ & Zhanjiang \\
\hline 6 & $<175$ & $<175$ & $<175$ & 182.78 & Zhanjiang \\
\hline 7 & $<175$ & 210.11 & $<175$ & $<175$ & Zhanjiang \\
\hline 8 & $<175$ & $<175$ & $<175$ & $<175$ & Zhanjiang \\
\hline 9 & $<175$ & 284.48 & $<175$ & $<175$ & Zhanjiang \\
\hline 10 & $<175$ & $<175$ & $<175$ & $<175$ & Zhanjiang \\
\hline 11 & $<175$ & 319.99 & $<175$ & 188.05 & Zhanjiang \\
\hline 12 & $<175$ & $<175$ & $<175$ & $<175$ & Shandong \\
\hline 13 & $<175$ & $<175$ & $<175$ & $<175$ & Shandong \\
\hline 14 & $<175$ & $<175$ & $<175$ & $<175$ & Shandong \\
\hline 15 & $<175$ & $<175$ & $<175$ & $<175$ & Shandong \\
\hline 16 & $<175$ & $<175$ & $<175$ & $<175$ & Shandong \\
\hline 17 & $<175$ & $<175$ & $<175$ & $<175$ & Shandong \\
\hline
\end{tabular}


Table 4. DSP contents measured by ELISA in scallops from Shandong and Zhanjiang

\begin{tabular}{|c|c|c|c|c|c|}
\hline Sample & $\begin{array}{l}\text { Adductor } \\
\text { muscle } \\
(\mu \mathrm{g} / 100 \mathrm{~g})\end{array}$ & $\begin{array}{l}\text { Visceral mass } \\
(\mu \mathrm{g} / 100 \mathrm{~g})\end{array}$ & $\begin{array}{l}\text { Mantle skirts } \\
(\mu \mathrm{g} / 100 \mathrm{~g})\end{array}$ & $\begin{array}{c}\text { Gill } \\
(\mu \mathrm{g} / 100 \mathrm{~g})\end{array}$ & Province \\
\hline 1 & $4.04 \pm 0.81$ & $4.31 \pm 0.86$ & $4.75 \pm 0.95$ & $4.91 \pm 0.98$ & Zhanjiang \\
\hline 2 & $4.83 \pm 0.97$ & $33.85 \pm 6.77$ & $5.4 \pm 1.08$ & $24.08 \pm 4.82$ & Zhanjiang \\
\hline 3 & $12.51 \pm 2.5$ & $10.16 \pm 2.03$ & $4.42 \pm 0.88$ & $14.9 \pm 2.98$ & Zhanjiang \\
\hline 4 & $6.5 \pm 1.3$ & $8.02 \pm 1.6$ & $5.78 \pm 1.16$ & $16.71 \pm 3.34$ & Zhanjiang \\
\hline 5 & $61.74 \pm 12.35$ & $142.04 \pm 28.41$ & $105.51 \pm 21.1$ & $142.04 \pm 28.41$ & Zhanjiang \\
\hline 6 & $44.88 \pm 8.98$ & $112.78 \pm 22.56$ & $23.93 \pm 4.79$ & $119.43 \pm 23.89$ & Zhanjiang \\
\hline 7 & $55.66 \pm 11.13$ & $119.43 \pm 23.89$ & $112.77 \pm 22.55$ & $74.01 \pm 14.8$ & Zhanjiang \\
\hline 8 & $5.33 \pm 1.07$ & $55.18 \pm 11.04$ & $5.21 \pm 1.04$ & $41.74 \pm 8.35$ & Zhanjiang \\
\hline 9 & $4.52 \pm 0.9$ & $34.54 \pm 6.91$ & $3.51 \pm 0.7$ & $55.66 \pm 11.13$ & Zhanjiang \\
\hline 10 & $4.96 \pm 0.99$ & $52.32 \pm 10.46$ & $3.96 \pm 0.79$ & $23.93 \pm 4.79$ & Zhanjiang \\
\hline 11 & $4 \pm 0.8$ & $37.44 \pm 7.49$ & $5.28 \pm 1.06$ & $22 \pm 4.4$ & Zhanjiang \\
\hline 12 & $3.52 \pm 0.7$ & $11.56 \pm 2.31$ & $5.58 \pm 1.12$ & $8.97 \pm 1.79$ & Shandong \\
\hline 13 & $5.85 \pm 1.17$ & $33.86 \pm 6.77$ & $4.31 \pm 0.86$ & $3.5 \pm 0.7$ & Shandong \\
\hline 14 & $3.37 \pm 0.67$ & $5.34 \pm 1.07$ & $3.78 \pm 0.76$ & $7.13 \pm 1.43$ & Shandong \\
\hline 15 & $5.14 \pm 1.03$ & $8 \pm 1.6$ & $5.46 \pm 1.09$ & $4.67 \pm 0.93$ & Shandong \\
\hline 16 & $5.93 \pm 1.19$ & $4.8 \pm 0.96$ & $4.2 \pm 0.84$ & $3.78 \pm 0.76$ & Shandong \\
\hline 17 & $4.92 \pm 0.98$ & $6.49 \pm 1.3$ & $5.25 \pm 1.05$ & $7.86 \pm 1.57$ & Shandong \\
\hline 18 & $5.42 \pm 1.08$ & $6.29 \pm 1.26$ & $3.36 \pm 0.67$ & $5.42 \pm 1.08$ & Zhanjiang \\
\hline 19 & $4.53 \pm 0.91$ & $5.15 \pm 1.03$ & $3.3 \pm 0.66$ & $5.27 \pm 1.05$ & Zhanjiang \\
\hline 20 & $5.57 \pm 1.11$ & $8.62 \pm 1.72$ & $4.21 \pm 0.84$ & $3.02 \pm 0.6$ & Zhanjiang \\
\hline
\end{tabular}




\section{ASP Contents}

ASP contents measured by ELISA are listed in Table 6. As shown, ASP was detectable in visceral mass and gills, but not adductor muscle or mantle skirts of scallops from both Zhanjiang and
Shandong. Scallops from Zhanjiang had higher ASP, with the maximum reaching $220.16 \mu \mathrm{g} / 100$ g. So far, the relevant standard for ASP has not yet been established, thus preventing assessment of whether the scallops were safe or not.

Table 5. DSP contents measured by mouse unit assay in scallops from Shandong and Zhanjiang

\begin{tabular}{|c|c|c|c|c|c|}
\hline Sample & $\begin{array}{l}\text { Adductor } \\
\text { muscle } \\
(\mathrm{MU} / 100 \mathrm{~g})\end{array}$ & $\begin{array}{c}\text { Visceral mass } \\
(\mathrm{MU} / 100 \mathrm{~g})\end{array}$ & $\begin{array}{c}\text { Mantle skirts } \\
(\mathrm{MU} / 100 \mathrm{~g})\end{array}$ & $\begin{array}{c}\text { Gill } \\
(\mathrm{MU} / 100 \mathrm{~g})\end{array}$ & Province \\
\hline 1 & $<0.05$ & $<0.05$ & $<0.05$ & $<0.05$ & Zhanjiang \\
\hline 2 & $<0.05$ & $<0.05$ & $<0.05$ & $<0.05$ & Zhanjiang \\
\hline 3 & $<0.05$ & $<0.05$ & $<0.05$ & $<0.05$ & Zhanjiang \\
\hline 4 & $<0.05$ & $<0.05$ & $<0.05$ & $<0.05$ & Zhanjiang \\
\hline 5 & 0.1 & 0.2 & 0.1 & 0.2 & Zhanjiang \\
\hline 6 & 0.1 & 0.1 & $<0.05$ & 0.1 & Zhanjiang \\
\hline 7 & 0.1 & 0.1 & 0.1 & 0.1 & Zhanjiang \\
\hline 8 & $<0.05$ & 0.1 & $<0.05$ & $<0.05$ & Zhanjiang \\
\hline 9 & $<0.05$ & $<0.05$ & $<0.05$ & 0.1 & Zhanjiang \\
\hline 10 & $<0.05$ & 0.1 & $<0.05$ & $<0.05$ & Zhanjiang \\
\hline 11 & $<0.05$ & $<0.05$ & $<0.05$ & $<0.05$ & Zhanjiang \\
\hline 12 & $<0.05$ & $<0.05$ & $<0.05$ & $<0.05$ & Shandong \\
\hline 13 & $<0.05$ & $<0.05$ & $<0.05$ & $<0.05$ & Shandong \\
\hline 14 & $<0.05$ & $<0.05$ & $<0.05$ & $<0.05$ & Shandong \\
\hline 15 & $<0.05$ & $<0.05$ & $<0.05$ & $<0.05$ & Shandong \\
\hline 16 & $<0.05$ & $<0.05$ & $<0.05$ & $<0.05$ & Shandong \\
\hline 17 & $<0.05$ & $<0.05$ & $<0.05$ & $<0.05$ & Shandong \\
\hline 18 & $<0.05$ & $<0.05$ & $<0.05$ & $<0.05$ & Zhanjiang \\
\hline 19 & $<0.05$ & $<0.05$ & $<0.05$ & $<0.05$ & Zhanjiang \\
\hline 20 & $<0.05$ & $<0.05$ & $<0.05$ & $<0.05$ & Zhanjiang \\
\hline
\end{tabular}


Table 6. ASP contents measured by ELISA in scallops from Shandong and Zhanjiang

\begin{tabular}{|c|c|c|c|c|c|}
\hline Sample & $\begin{array}{l}\text { Adductor } \\
\text { muscle } \\
(\mu \mathrm{g} / 100 \mathrm{~g})\end{array}$ & $\begin{array}{l}\text { Visceral mass } \\
(\mu \mathrm{g} / 100 \mathrm{~g})\end{array}$ & $\begin{array}{l}\text { Mantle skirts } \\
(\mu \mathrm{g} / 100 \mathrm{~g})\end{array}$ & $\begin{array}{c}\text { Gill } \\
(\mu \mathrm{g} / 100 \mathrm{~g})\end{array}$ & Province \\
\hline 1 & $3.17 \pm 0.32$ & $2.87 \pm 0.29$ & $2.94 \pm 0.29$ & $4.03 \pm 0.4$ & Zhanjiang \\
\hline 2 & $10.32 \pm 1.03$ & $64.04 \pm 6.4$ & $7.1 \pm 0.71$ & $47.59 \pm 4.76$ & Zhanjiang \\
\hline 3 & $3.49 \pm 0.35$ & $5.71 \pm 0.57$ & $3.05 \pm 0.31$ & $78.7 \pm 7.87$ & Zhanjiang \\
\hline 4 & $3.43 \pm 0.34$ & $23.9 \pm 2.39$ & $9.5 \pm 0.95$ & $22.51 \pm 2.25$ & Zhanjiang \\
\hline 5 & $5.3 \pm 0.53$ & $4.35 \pm 0.44$ & $3.98 \pm 0.4$ & $5.35 \pm 0.54$ & Zhanjiang \\
\hline 6 & $5.05 \pm 0.51$ & $220.16 \pm 2.2$ & $6.03 \pm 0.6$ & $39.75 \pm 3.98$ & Zhanjiang \\
\hline 7 & $4.95 \pm 0.5$ & $2.96 \pm 0.3$ & $3.74 \pm 0.37$ & $5.63 \pm 0.56$ & Zhanjiang \\
\hline 8 & $3.52 \pm 0.35$ & $3.66 \pm 0.37$ & $3.42 \pm 0.34$ & $3.07 \pm 0.31$ & Zhanjiang \\
\hline 9 & $2.53 \pm 0.25$ & $27.92 \pm 2.79$ & $1.57 \pm 0.16$ & $32.16 \pm 3.22$ & Zhanjiang \\
\hline 10 & $2.57 \pm 0.26$ & $12.3 \pm 1.23$ & $4.36 \pm 0.44$ & $76.82 \pm 7.68$ & Zhanjiang \\
\hline 11 & $2.17 \pm 0.22$ & $40.28 \pm 4.03$ & $1.39 \pm 0.14$ & $69.77 \pm 6.98$ & Zhanjiang \\
\hline 12 & $3.73 \pm 0.37$ & $58.25 \pm 5.83$ & $2.09 \pm 0.21$ & $21.26 \pm 2.13$ & Shandong \\
\hline 13 & $1.33 \pm 0.13$ & $16.89 \pm 1.69$ & $1.57 \pm 0.16$ & $8.2 \pm 0.82$ & Shandong \\
\hline 14 & $1.7 \pm 0.17$ & $19.79 \pm 1.98$ & $2.74 \pm 0.27$ & $5.43 \pm 0.54$ & Shandong \\
\hline 15 & $3.45 \pm 0.35$ & $19.19 \pm 1.92$ & $1.22 \pm 0.12$ & $7.9 \pm 0.79$ & Shandong \\
\hline 16 & $4.55 \pm 0.46$ & $22.4 \pm 2.24$ & $2.69 \pm 0.27$ & $7.44 \pm 0.74$ & Shandong \\
\hline 17 & $2.46 \pm 0.25$ & $15.41 \pm 1.54$ & $2.16 \pm 0.22$ & $7.13 \pm 0.71$ & Shandong \\
\hline 18 & $1.19 \pm 0.12$ & $84.04 \pm 8.4$ & $2.33 \pm 0.23$ & $7.1 \pm 0.71$ & Zhanjiang \\
\hline 19 & $2.76 \pm 0.28$ & $2.29 \pm 0.23$ & $1.23 \pm 0.12$ & $4.82 \pm 0.48$ & Zhanjiang \\
\hline 20 & $2.21 \pm 0.22$ & $3.43 \pm 0.34$ & $3.12 \pm 0.31$ & $3.42 \pm 0.34$ & Zhanjiang \\
\hline
\end{tabular}


Table 7. NSP contents measured by ELISA in scallops from Shandong and Zhanjiang

\begin{tabular}{|c|c|c|c|c|c|}
\hline Sample & $\begin{array}{l}\text { Adductor } \\
\text { muscle } \\
(\mu \mathrm{g} / 100 \mathrm{~g})\end{array}$ & $\begin{array}{l}\text { Visceral mass } \\
(\mu \mathrm{g} / 100 \mathrm{~g})\end{array}$ & $\begin{array}{c}\text { Mantle skirts } \\
(\mu \mathrm{g} / 100 \mathrm{~g})\end{array}$ & $\begin{array}{c}\text { Gill } \\
(\mu \mathrm{g} / 100 \mathrm{~g})\end{array}$ & Province \\
\hline 1 & $0.25 \pm 0.08$ & $0.35 \pm 0.11$ & $0.04 \pm 0.01$ & $0.16 \pm 0.05$ & Zhanjiang \\
\hline 2 & $0.26 \pm 0.08$ & $0.36 \pm 0.11$ & $0.01 \pm 0$ & $0.44 \pm 0.13$ & Zhanjiang \\
\hline 3 & $0.22 \pm 0.07$ & $0.3 \pm 0.09$ & $0.03 \pm 0.01$ & $0.14 \pm 0.04$ & Zhanjiang \\
\hline 4 & $0.37 \pm 0.11$ & $0.52 \pm 0.16$ & $0 \pm 0$ & $0.21 \pm 0.06$ & Zhanjiang \\
\hline 5 & $0.27 \pm 0.08$ & $0.37 \pm 0.11$ & $0.02 \pm 0.01$ & $0.13 \pm 0.04$ & Zhanjiang \\
\hline 6 & $0.36 \pm 0.11$ & $0.51 \pm 0.15$ & $0.03 \pm 0.01$ & $0.17 \pm 0.05$ & Zhanjiang \\
\hline 7 & $0.18 \pm 0.05$ & $0.25 \pm 0.08$ & $0.01 \pm 0$ & $0.12 \pm 0.04$ & Zhanjiang \\
\hline 8 & $0.36 \pm 0.11$ & $0.5 \pm 0.15$ & $0.03 \pm 0.01$ & $0.16 \pm 0.05$ & Zhanjiang \\
\hline 9 & $0.26 \pm 0.08$ & $0.36 \pm 0.11$ & $0 \pm 0$ & $0.03 \pm 0.01$ & Zhanjiang \\
\hline 10 & $0.28 \pm 0.08$ & $0.39 \pm 0.12$ & $0.04 \pm 0.01$ & $0.03 \pm 0.01$ & Zhanjiang \\
\hline 11 & $0.21 \pm 0.06$ & $0.3 \pm 0.09$ & $0.01 \pm 0$ & $0.02 \pm 0.01$ & Zhanjiang \\
\hline 12 & $0.42 \pm 0.13$ & $0.59 \pm 0.18$ & $0.02 \pm 0.01$ & $0.04 \pm 0.01$ & Shandong \\
\hline 13 & $0.22 \pm 0.07$ & $0.3 \pm 0.09$ & $0 \pm 0$ & $0 \pm 0$ & Shandong \\
\hline 14 & $0.23 \pm 0.07$ & $0.33 \pm 0.1$ & $0.01 \pm 0$ & $0.03 \pm 0.01$ & Shandong \\
\hline 15 & $0.12 \pm 0.04$ & $0.17 \pm 0.05$ & $0.22 \pm 0.07$ & $0.04 \pm 0.01$ & Shandong \\
\hline 16 & $0.31 \pm 0.09$ & $0.44 \pm 0.13$ & $0.61 \pm 0.18$ & $0.02 \pm 0.01$ & Shandong \\
\hline 17 & $0.16 \pm 0.05$ & $0.22 \pm 0.07$ & $0.19 \pm 0.06$ & $0 \pm 0$ & Shandong \\
\hline 18 & $0.27 \pm 0.08$ & $0.38 \pm 0.11$ & $0.29 \pm 0.09$ & $0.03 \pm 0.01$ & Zhanjiang \\
\hline 19 & $0.12 \pm 0.04$ & $0.17 \pm 0.05$ & $0.19 \pm 0.06$ & $0.03 \pm 0.01$ & Zhanjiang \\
\hline 20 & $0.27 \pm 0.08$ & $0.38 \pm 0.11$ & $0.24 \pm 0.07$ & $0.02 \pm 0.01$ & Zhanjiang \\
\hline
\end{tabular}

\section{NSP Contents}

Table 7 shows that NSP contents in scallops from Zhanjiang and Shandong were lower than the detection limit, $0.45 \mu \mathrm{g} / 100$ $\mathrm{g}$, indicating that the scallops contained little or no NSP.

\section{DISCUSSION}

Toxins produced by algae can be transformed or accumulated in humans through scallops and other marine organisms in the food chain. Some shellfish biotoxins can affect both marine animals and man, whilst others affect humans 
alone (12). Among them, PSP and DSP are most common toxins $(8,12,13)$. In particular, PSP has been considered to be among the most harmful and widely distributed toxins worldwide (14). The toxins are generally accumulated in shellfish bodies. But depending on the species, they are accumulated in different tissues and organs. For example, toxins can be rapidly accumulated in mussels and scallops, mostly in the digestive tract, ventricle, mantle skirts or gills. Some toxins can remain in shellfish for months or even years (15).

Today, shellfish toxins are normally examined by means of the mouse unit assay, ELISA, or high performance liquid chromatography (HPLC). Mouse unit assay is the designated standard method for detection of shellfish poisonings in Japan and other countries with a high incidence of shellfish poisoning. Although it is technically easy to master and does not require specialized equipment, the method is quite complex operatively and lacks specificity; in another words, it cannot distinguish among different type of toxins (16-18).

HPLC can accurately and quantitatively identify various components of toxins. However, the method is limited by a lack of standard materials and it requires expensive equipment, so that it is not suitable for large-scale screening. Compared with the above two methods, ELISA is very specific, highly sensitive and rapid, and requires a very small amount of sample. Therefore, it permits simultaneous examination of many samples, obtains results in a very short period and is suitable for rapid screening of shellfish toxins (19).

In the present study, we first conducted preliminary screening using ELISA and further reevaluated the results by the mouse unit assay to ensure their accuracy and reliability (20). We found that PSP was accumulated mainly in the visceral mass and gills of scallops; only small amounts were accumulated in mantle skirts, but none was detected in adductor muscle. In contrast, DSP was accumulated not only in adductor muscle and mantle skirts but also in gills and visceral mass at high levels, especially in the latter two areas. Like PSP, ASP was only accumulated in visceral mass and gills at very high levels, but not in mantle skirts or adductor muscle. NSP was undetectable in scallops from Shandong and Zhanjiang. The differences in toxin distributions between the tissues might be due to the different functions of the organs or tissues. For example, visceral mass and gills are the main organs to metabolize the toxins, while mantle skirts and adductor muscle are irrelevant to toxin metabolization. Furthermore, such tissue and organ variability may be on account of differences in blood supply or lipid content, which must be validated in future research.

In addition, shellfish toxins present diverse geographical distribution. Scallops from Shandong had very low shellfish toxin levels, whereas those from Zhanjiang were much higher, some several times above the national limit, which may be related to such aspects of the local marine environments as climatic condition, sanitation status, water eutrophication, algae species, algae quantity and even contamination.

To reduce the impact of shellfish poisonings on human health, it is recommended that, firstly, people should not eat visceral mass or gills since they might accumulate very high toxin levels, and secondly, mantle skirts and adductor muscle should be cleaned and boiled thoroughly before eating (7). In addition, a sound monitoring system should be established to monitor red tide in order to prevent accumulation of shellfish toxins in scallops caused by environmental pollution.

\section{COPYRIGHT}

(c) CEVAP 2011

\section{SUBMISSION STATUS}

Received: October 28, 2010.

Accepted: January 25, 2011.

Abstract published online: January 26, 2011.

Full paper published online: February 28, 2011.

\section{CONFLICTS OF INTEREST}

There is no conflict.

\section{FINANCIAL SOURCE}

National High Technology Research and Development Program of China (863 Program, 2006AA02A311), Guangdong Science and Technology Department (93085) and Guangzhou municipal bureau of Science and Technology (2009Z1-E061) provided the financial grants.

\section{ETHICS COMMITTEE APPROVAL}

The present study was approved by the Ethics Committee for Animal Experimentation of the 
Guangzhou Center for Disease Control and Prevention, Guangzhou, People's Republic of China.

\section{CORRESPONDENCE TO}

WEI ZHU, Department of Toxicology, Guangzhou Center for Disease Control and Prevention, Guangzhou, Guangdong, 510080, People's Republic of China. Phone: 86-2036545123, Email: zhuyc126@126.com.

\section{REFERENCES}

1. Torgersen T, Lindegarth S, Ungfors A, Sandvik M. Profiles and levels of fatty acid esters of okadaic acid group toxins and pectenotoxins during toxin depuration. Part I: brown crab (Cancer pagurus). Toxicon. 2008;52(3):407-17.

2. Moustafa A, Loram JE, Hackett JD, Anderson DM, Plumley FG, Bhattacharya D. Origin of saxitoxin biosynthetic genes in cyanobacteria. PLoS One. 2009; 4(6):e5758.

3. Rundberget T, Gustad E, Samdal IA, Sandvik $\mathrm{M}$, Miles CO. A convenient and cost-effective method for monitoring marine algal toxins with passive samplers. Toxicon. 2009;53(5):543-50.

4. Jiang TJ, Wang DZ, Niu T, Xu YX. Trophic transfer of paralytic shellfish toxins from the cladoceran (Moina mongolica) to larvae of the fish (Sciaenops ocellatus). Toxicon. 2007;50(5):639-45.

5. Torgersen T, Miles CO, Rundberget T, Wilkins AL. New esters of okadaic acid in seawater and blue mussels (Mytilus edulis). J Agric Food Chem. 2008;56(20):9628-35.

6. Selwood AI, Ginkel R, Wilkins AL, Munday R, Ramsdell JS, Jensen DJ, et al. Semisynthesis of S-desoxybrevetoxin-B2 and brevetoxin-B2, and assessment of their acute toxicities. Chem Res Toxicol. 2008;21(4):944-50.

7. Berenguer JA, Gonzalez L, Jimenez I, Legarda TM, Olmedo JB, Burdaspal PA. The effect of commercial processing on the paralytic shellfish poison (PSP) content of naturally-contaminated Acanthocardia tuberculatum L. Food Addit Contam. 1993;10(2):217-30.

8. Fleming LE, Easom J, Baden D, Rowan A, Levin B. Emerging harmful algal blooms and human health: Pfiesteria and related organisms. Toxicol Pathol. 1999;27(5):573-81.

9. AOAC. Official methods of analysis of AOAC. $18^{\text {th }}$ ed. Gaithersburg, MD: AOAC International, 2005.

10. Combes $\mathrm{RD}$. The mouse bioassay for diarrhetic shellfish poisoning: a gross misuse of laboratory animals and of scientific methodology. Altern Lab Anim. 2003;31(6):595-610.
11. General Administration of Quality Supervision, Inspection and Quarantine of the People's Republic of China. Safety Qualification for Agricultural Product - Safety Requirement for Non-environmental Pollution Aquatic Products (GB18406.4-2001). Beijing: China Standard Press; 200. p. 69-70.

12. Viviani R. Eutrophication, marine biotoxins, human health. Sci Total Environ. 1992;Suppl:631-62.

13. Reboreda A, Lago J, Chapela MJ, Vieites JM, Botana LM, Alfonso A, et al. Decrease of marine toxin content in bivalves by industrial processes. Toxicon. 2010;55(2-3):235-43.

14. Lehane $M$, Fidalgo Sáez $M J$, Magdalena $A B$, Ruppén Cañás I, Díaz Sierra M, Hamilton B, et al. Liquid chromatography - multiple tandem mass spectrometry for the determination of ten azaspiracids, including hydroxyl analogues in shellfish. J Chromatogr A. 2004;1024(1-2):63-70.

15. Blanco J, Mariño C, Martín H, Acosta CP. Anatomical distribution of diarrhetic shellfish poisoning (DSP) toxins in the mussel Mytilus galloprovincialis. Toxicon. 2007;50(8):1011-8.

16. Draisci R, Croci L, Giannetti L, Cozzi L, Lucentini L, De Medici D, Stacchini A. Comparison of mouse bioassay, HPLC and enzyme immunoassay methods for determining diarrhetic shellfish poisoning toxins in mussels. Toxicon. 1994; 32(11):1379-84.

17. Usleber E, Donald M, Straka M, Martlbauer E. Comparison of enzyme immunoassay and mouse bioassay for determining paralytic shellfish poisoning toxins in shellfish. Food Addit Contam. 1997;14(2):193-8.

18. Inami GB, Crandall C, Csuti D, Oshiro $M$, Brenden RA. Feasibility of reduction in use of the mouse bioassay: presence/absence screening for saxitoxin in frozen acidified mussel and oyster extracts from the coast of California with in vitro methods. J AOAC Int. 2004;87(5):1133-42.

19. Turner AD, Norton DM, Hatfield RG, Morris $S$, Reese AR, Algoet M, et al. Refinement and extension of AOAC Method 2005.06 to include additional toxins in mussels: single-laboratory validation. J AOAC Int. 2009;92(1):190-207.

20. Garet E, González-Fernández A, Lago J, Vieites JM, Cabado AG. Comparative evaluation of enzyme-linked immunoassay and reference methods for the detection of shellfish hydrophilic toxins in several presentations of seafood. J Agric Food Chem. 2008;58(3):1410-5. 